\title{
Density of tryptase-positive mast cells correlated with the presence of $H$. pylori in gastric neoplasia
}

\author{
GIANINA MICU ${ }^{1}$, FLORICA STĂNICEANU ${ }^{1,2}$, LIANA STICLARU ${ }^{1}$, CRISTIANA POPP ${ }^{1}$, ALEXANDRA BASTIAN $^{1,2}$, \\ ELIZA GRAMADÄ ${ }^{1}$, M. RIMBAȘ 2,3, B. MATEESCU ${ }^{2,3}$ \\ 1“Colentina” Clinical Hospital, Department of Pathology, Bucharest, Romania \\ 2“"Carol Davila” University of Medicine, Bucharest, Romania \\ 3“"Colentina" Clinical Hospital, Department of Gastroenterology, Bucharest, Romania
}

\begin{abstract}
Background. Gastric cancer continues to be a platoon leader of mortality causes. A significant number of recent studies show direct or indirect involvement of mast cells (MC), with a complex role both pro- and anti-tumor growth.

Aim. To objectify the correlations between expression of MC and presence of Helicobacter pylori (HP) infection depending on neoplastic nature of the gastric damage.

Subjects and Methods. The study was carried out on archival samples of gastric wall from 30 patients with gastric cancer versus 30 age and sex-matched subjects with gastric surgery for nonneoplastic diseases. The inclusion criteria for the case group were histologically proven stage T3/T4 malignancies with regional lymph node metastases. For each case of the study group, distribution and number of MC tryptase positive (DMC-TP) were analyzed in five different areas from the same gastrectomy specimen: intratumor area, deep and side tumor invasion front, normal gastric tissue sample $5-10 \mathrm{~cm}$ or more distant from the tumor and furthest resection margin.

Results. Independently of HP infection, the study recorded a significantly lower value of DMC-TP in male patients. In regions with inflammatory lesions and preneoplastic changes and in control cases with non-gastric neoplasia, the DMC-TP level was higher than controls with HP-related inflammatory pathology, thus removing bacterial etiology from the forefront of $\mathrm{MC}$ mobilizing causes.

Conclusion. The presence of $H$. pylori infection was not found to cause significant changes in terms of mobilizing mast cells in the gastric wall with advanced tumors, with minimal stage III TNM.
\end{abstract}

Key words: mast cells, tumor microenvironment, Helicobacter pylori, tryptase, gastric preneoplastic lesions.

\section{BACKGROUND AND AIMS}

Gastric cancer continues to be the second leading cause of cancer-related death worldwide. Despite the decreasing global incidence and major advances in therapeutic strategies, gastric cancer mortality declined at a very slow rate over the past several decades [1]. Since Helicobacter pylori (HP) had been recognized as a first class carcinogen for gastric cancer, a large number of studies have revealed the role of different individual bacterial virulence and host factors that contribute to multistep gastric carcinogenesis, thus providing a better understanding on host-pathogen interaction. Persistent HP infection outcome depends on a complex interplay of strain-specific bacterial constituents, host genetic background that governs the immune responses and environmental influences $[2,3]$. The precise mechanisms involved in gastric cancer development in response to this infection are still incompletely defined.
The multistage progression from normal gastric epithelium to an invasive gastric malignancy is a multiply-conditioned process associated with or supported by the tumor microenvironment, which essentially involves dynamic interaction between cancer-infiltrating cells, inflammatory cells vasculature, stromal cells, tumor vasculature, extracellular matrix, and other matrix-associated molecules. The local microenvironment represents the key element in regulating the behavior of cells residing in the tumor niche either towards aggressiveness (proliferation, invasiveness, metastasizing, refractoriness to treatment, relapse), or towards hibernation ("dormancy tumor") $[4,5]$.

Studies in the past decade regarding the emergence, growth and dissemination of tumors have focused increasingly on tumor microenvironment (ETM). The tumor grows in a microenvironment whose two components seem to coexist and continuously influence each other: one physical (including cell elements - fibroblasts, immune cells 
and matrix), the other physiological (including exchange of nutrients and waste carried out through the tumor's vascular network) [6-8].

The tumor-host interface is in a constant remodeling. This is predominantly accomplished by factors belonging to the host and less by those produced by the tumor. Out of these, mast cells, with their enzymes, including tryptase, play a central role in tumor growth, angiogenesis, stromal modeling $[9,10]$.

As an important component of the tumor microenvironment, mast cells could participate in expansion and maturation of gastric tumor niche, promoting tumor growth and progression, but there is still debate concerning pro- versus antitumor effects of mast cells. Mast cells can be recruited by tumor-derived chemoattractant. Through the secretion of various molecules such as growth factors, cytokines, histamine, heparin, VEGF, IL-8, IL-6, TNF, MMP-8 and MMP-9, iNOSCOX-2, proteases which allow the formation of neo-vessels etc., their action is complex, the concern to discover its many roles being currently the subject of numerous researches $[8,11,12]$. Out of the roles assigned to mast cells we mention as noteworthy for the present study: the role of $\mathrm{T}$ lymphocytes modulator (e.g. iTreg, Tc1, Th17), the role of angiogenesis inducer - some studies considering as decisive the induction by mast cells of "switch angiogenesis" which precedes malignant transformation; roles in apoptosis, intervention in cell cycle and influencing intercellular adhesiveness. Beyond these actions and roles, mast cells are nowadays assigned a significant role of modulator of tumor microenvironment, their involvement in neoplasia progression, invasiveness of metastasis and cancer cells being possible in study [9]. Work hypothesis: mast cells are involved in tumor biology. Practical consequence: mast cells modulators can improve, in certain circumstances, anti-tumor therapy $[9,13]$.

\section{MATERIALS AND METHODS}

\section{Patients and study design}

We designed a retrospective case-control study in order to investigate the association between gastric cancer, the density of mast cells and the presence of HP infection. The study was carried out on archival samples of gastric wall obtained from 30 patients (17 males, 13 females, with an average 5th decade of life) with gastrectomy performed for neoplastic disease of the stomach over a period of 5 years (July 2009 - June 2014). The control group consisted of tissue samples from 30 age and sexmatched subjects with no history of gastric cancer who underwent gastric surgery for other diseases, such as pyloric stenosis, gastric/duodenal ulcer, gastric polyps or non-gastric neoplasia (segmental gastrectomy for pancreatic, colonic and extra-hepatic bile ducts cancers) also over July 2009 - June 2014 interval. The inclusion criteria for the case group were histologically proven stage T3/T4 malignancies with regional lymph node metastases and written informed consent from each patient. Cases with $\mathrm{T} 1$ or T2 tumoral stage and patients who received preoperative treatment such as radiation and chemotherapy were excluded.

\section{Methods}

For each case of the study group, mast cell density and distribution were analyzed in five different areas from the same gastrectomy specimen: intratumor area (IT), deep tumor invasion front (DTIF), lateral tumor invasion front (LTIF), normal gastric wall sampled $5 \mathrm{~cm}$ or more distant from the tumor (NGW) and resection margin most distant from tumor (RM); the data were compared with the mast cell density and distribution in the age and sex-matched control specimen. For the simultaneous evaluation of these areas we used an efficient, rapid and flexible method - multi-tissue blocks. Five cubical cores of $0.5 / 0.5 / 0.2 \mathrm{~cm}^{3}$ were dissected from each tumor case; they were extracted from five standard paraffin blocks corresponding to the above-mentioned areas of interest and placed into single empty "recipient" block. Every multi-tissue block thus generated contained, in addition, a control core obtained from non-tumoral gastric specimens, so that six individuals' tissue samples (five from tumoral specimens and one from control group) were organized on one glass slide. Advantages of this unconventional technique included great economy in reagents, antibodies, tissue samples and time, as well as the possibility of examining multiple tissue specimens under identical conditions [14].

Each multi-tissue paraffin block was routinely cut in $5 \mu \mathrm{m}$-thick sections. Before use, slides were deparaffinized, rehydrated and processed for routine haematoxylin and eosin (H\&E) and Giemsa staining and immunohistochemistry. The morphological tumoral features - the grade of histologic differentiation, the presence of perivascular and perineural invasion or lymphatic tumor emboli were assessed on H\&E stained specimens. For assessment of HP infection status Giemsa stain technique was used. 
Immunohistochemical (IHC) analysis was performed by using indirect streptavidin-peroxidase method with specific primary antibody against mast cell tryptase (AA1, DakoCytomation, Glostrup, Denmark) [14]. After antigen unmasking in EDTA buffer in a microwave oven at $100 \mathrm{~W}$ power for 1520 minutes and washing with distilled water, TBS buffer, endogenous peroxidase was blocked within 15 minutes. Exposure time to the primary antibodies was 30 minutes at room temperature. Sections were incubated with streptavidin-peroxidase complex and DAB-substrate and were further counterstained with Giemsa.

Examination of the sections and image acquisition were performed using an Olympus BX43 microscope equipped with an Olympus XC30 digital camera (Olympus Corporation, Japan). The IHC sections were initially scanned at low power $(\times 100)$ magnification in order to identify the areas with greatest positive staining. Then, 10 microscopic high power fields $(\times 400)$ were captured for each of the six individual tissue samples to count immunoreactive mast cells and to analyze their distribution. We selected the number of 10 fields per sample, as this was the lowest number of mast cell containing fields found in sections obtained from all the specimens. Identical microscope and camera settings were used for each capture within the study.

Statistical analysis of the results was performed using the statistical analysis package Microsoft Office Excel 2007. Graph Pad software was used. The arithmetic mean value (M) and the standard error of the mean $(\mathrm{m})$ were determined. To identify the probability of significance of differences of compared average values Student test was used. With the $t$ test we have compared the same variable (DMC-TP) for two different groups. Differences were considered statistically significant at the $5 \%$ significance level $(\mathrm{P}<0.05)$. Mast cells immunohistochemically marked with Tryptase (MC-TP), counterstained with Giemsa; HPF.

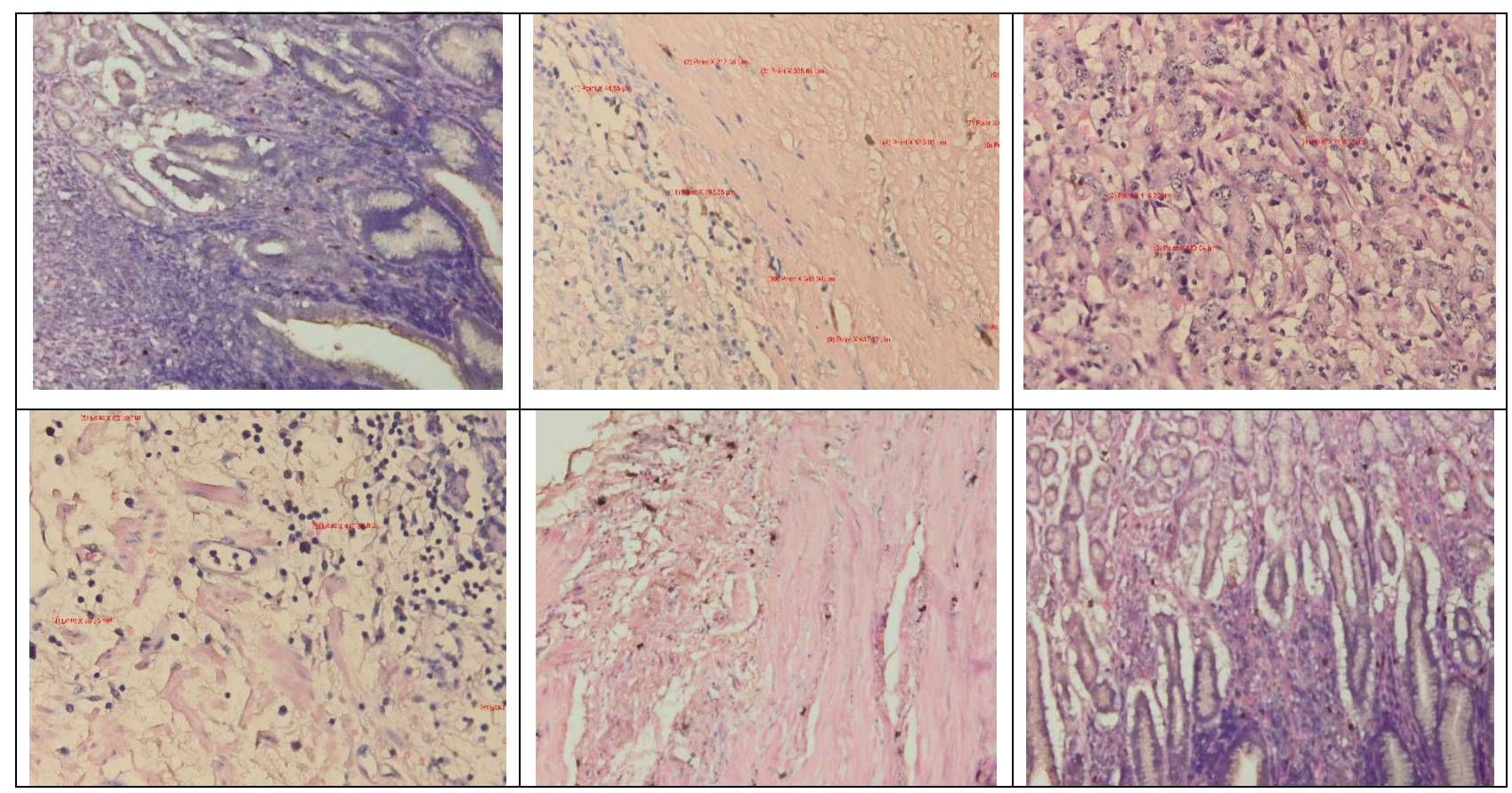

Legend: Photo 1 - presence of MC-TP in polymorph chronic infiltrate in chronic gastritis HP-; Photo 2 - presence of C/TP at the level of resection margin most distant from tumor (part of the total gastrectomy for malignancy); Photo 3 -intra-tumor MC-TP; Photo 4 and Photo 5-MC-TP at the level of the lateral tumor-invasion front, namely in-depth; Photo 6-gastric wall 10cm away from the tumor.

We have studied the presence of mast cells in the inflammatory infiltrate from the non-tumor gastric wall (control cases) and tumor gastric wall, depending on the presence or absence of HP. We investigated the distribution and number of mast cells (DMC-TP) immunohistochemically marked with tryptase and counterstained with Giemsa.

We compared values of DMC-TP in different areas:
- in each case from the tumor group between different regions of the gastric wall as it follows:

- intra-tumor fragment (IT) versus resection margin most distant from tumor (RM)

- intra-tumor fragment (IT) versus lateral tumor invasion front (LTIF)

- intra-tumor fragment (IT) versus deep tumor invasion front (DTIF) 
- intra-tumor fragment (IT) versus normal gastric wall sampled $5 \mathrm{~cm}$ or more distant from the tumor (NGW)

- resection margin most distant from tumor (RM) versus lateral tumor invasion front (LTIF)

- resection margin most distant from tumor (RM) versus deep tumor invasion front (DTIF)

- resection margin most distant from tumor (RM) versus normal gastric wall (NGW)).

- between different areas of each tumor case and case control as it follows:

- intra-tumor area (IT) versus matched control

- deep tumor invasion front (DTIF) versus matched control

- lateral tumor invasion front (LTIF) versus matched control

- normal gastric wall sampled $5 \mathrm{~cm}$ or more distant from the tumor (NGW) versus matched control

- resection margin most distant form tumor (RM) versus matched control).

\section{RESULTS AND DISCUSSION}

\section{a. General results and discussion}

Independent of the presence of HP infection, the study recorded a DMC-TP value significantly lower in male patients, both in the non-tumor gastric wall, and in tumor cases. Increased reactivity of the female body is likely to have among explanations specific hormonal impregnation [10, 11]. Most tumor cases (20 cases - 67\%) in stage pT3pM1 had the lowest density of MC-TP in intratumor compartment (IT), while at DTIF level and especially NGW the DMC-TP values were very high, suggesting an increased reaction of the body to limit tumor extension: local expansion slowed (only pT3, already M1) [9].

In regions with inflammatory lesions accompanied by pre-neoplastic changes (intestinal metaplasia and mild and moderate epithelial dysplasia) and in control cases from patients with no gastric malignancies (pancreatic and biliary cancers), the DMC-TP level was higher than that in inflammatory HP cases, thus removing bacterial etiology from the forefront of MC mobilizing causes $[15,16]$.

We have encountered several cases of tumors pT4a, both HP+ (cases XVI, XVII, XXII, XXIII) and HP- (cases IV, VIII, X, XII) with very low DMC-TP values in DTIF areas, significantly lower than the mean value obtained for this category

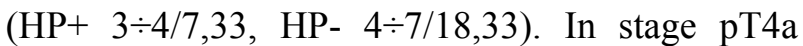
tumor penetrates serosa and invades the visceral peritoneum. Mast cells are part of cellular component of the host's general inflammatory response, along with macrophage and endothelial cells. Comparing our data with the study of JiménezHeffernan, José A; Bajo, et al. who determined the number of $\mathrm{MC}$ in the peritoneum as frequent as $7.13+/-0.67$, the number of MC-TP in our cases in similar locations was lower than Jiménez-Heffernan's data (5), thus explaining peritoneal symptomatology of targeted patient and bearing a poor prognostic significance [16]. In these cases, the host's immune response seems diminished. Other cases pT4 (cases II, II, VI) which have superior DMC-TP values at DTIF level than that of Jiménez-Heffernan study, emphasized peritoneal reactivity.

In one fifth of cases (cases XII, XIII, XV, XIX, XXIV, XXIX), DMC-TP in both intra-tumor and NGW locations was similar. These findings (higher values of DMC-TP in invasion fronts compared with intra-tumor or normal gastric wall values) argue in favor of the role of MCs in limiting tumor extension $[9,17,18]$.

In cases of diffuse gastric signet ring cell carcinomas, DMC-TP values were low in all compartments studied; however, comparing these data with data recorded in cases of intestinal type gastric cancer, DMC-TP in LTIF was generally higher compared with all the other regions we studied. As recorded also by literature, DMC-TP in poorly differentiated gastric cancer are significantly below average, especially in IT, DTIF and NGW areas [9, $17,19]$.

Tumor invasion fronts (the part of the peritumor microenvironment tangent to the tumor) were found to have higher values in deep area (DTIF) compared to the other regions studied in patients with lower age decades (under 50 years old), while in patients with advanced age (age decades 6-8) higher DMC-TP values were recorded in lateral (LTIF).

In some cases (cases XII, XV, XXIV) we recorded a peculiar distribution of mast cells: low value of DMC-TP in the invasion fronts (both LTIF and DTIF); similar values of DMC-TP in IT and control; DMC-TP in NGW above average value. These data support the hypothesis that in these cases the body reacts to the entire [tumor+ tumor microenvironment] complex, trying to limit tumor expansion. The three cases are particular through this profile of DMC-TP, its similar values in IT and $\mathrm{RM}$ areas describing a balance between tumor and host; thus, from this aspect, the tumor is "inactive" and therefore immunologically "mute" - we could 
say dumbing by the host immune response; since the vast majority of our cases had an intra-tumor value DMC-TP smaller / much smaller than at RM level ("internal control"), our data show a high reactivity of the host; only at the periphery of the tumor, in its growing invasive front, mast cells are fewer in number compared to the internal control and the average value of cases; this may indicate that either the tumor is growing slowly, evolving chronically or the tumor is caught in a dormant phase at the moment of the excision [20]. It is interesting to interpret the significant difference of the host's responsiveness to the interface with the tumor, at $5-10 \mathrm{~cm}$ distance of tumor in the most distant area from the tumor (RM - internal control): a "collapse" of peri-tumor DMC and a massive increase of it at a relative distance from the tumor.

In all six cases of non-epithelial tumors - two GIST (case XIV (HP-) and case XXII (HP+)), one leiomyosarcoma (case VII (HP-)) and one nonHodgkin lymphoma (NHL) (case XX1 (HP+)) the DMC-TP values were very low at IT level (reaching up to 5 times less than average, given that $83.33 \%$ of the studied tumors were carcinomas) and up to 5 times lower than the
DMC-TP at RM level (internal control). One explanation for this difference may derive from the fact that the epithelial tumor "comes" with an epithelial component, but also a desmoplastic one, which would have increased tropism at inflammatory elements compared to non-epithelial tumors $[21,22]$; the presence of HP did not make a difference in behavior in this case either.

The vast majority of HP + cases had low / very low values of DMC-TP in intra- and peri-tumor compartments (IT, DTIF, LTIF) and significantly higher values of DMC-TP in non-tumor areas (RM, NGW) where non-neoplastic gastric mucosa colonized by bacteria specifically reacted to its presence.

b.Statistical significance of results obtained in cases without $H$. pylori (HP-) infection, respectively with infection of gastric mucosa $(\mathrm{HP}+)$. Discussion

We calculated the percentage of results with statistical significance (SS) obtained in each case, mentioning the extremely statistically significant (ES) and, in particular, those with $\mathrm{P}<0.0001$, as they can be seen in the tables below:

Table 1

\begin{tabular}{|l|c|c|c|c|c|}
\hline \multicolumn{1}{|c|}{ HP- } & C/RM & C/IT & C/LTIF & C/DTIF & C/NGW \\
\hline $\begin{array}{l}\text { NS } \\
(\mathbf{P}>\mathbf{0 . 0 5})\end{array}$ & $33.33 \%$ & $13.33 \%$ & $40 \%$ & $26.66 \%$ & $20 \%$ \\
\hline $\begin{array}{l}\mathbf{S S} \\
(\mathbf{P}<\mathbf{0 . 0 5})\end{array}$ & $66.66 \%$ & $86.66 \%$ & $60 \%$ & $73.33 \%$ & $80 \%$ \\
\hline $\begin{array}{l}\boldsymbol{E S} \\
\mathbf{P}<\mathbf{0 . 0 0 0 1}\end{array}$ & $33.33 \%$ & $46.66 \%$ & $33.34 \%$ & $60 \%$ & $66.66 \%$ \\
\hline
\end{tabular}

Table 2

\begin{tabular}{|l|c|c|c|c|c|}
\hline \multicolumn{1}{|c|}{ HP+ } & C/RM & C/IT & C/LTIF & C/DTIF & C/NGW \\
\hline $\begin{array}{l}\mathbf{N S} \\
(\mathbf{P}>\mathbf{0 . 0 5})\end{array}$ & $60 \%$ & $20 \%$ & $46.66 \%$ & $40 \%$ & $40 \%$ \\
\hline $\begin{array}{l}\mathbf{S S} \\
(\mathbf{P}<\mathbf{0 . 0 5})\end{array}$ & $40 \%$ & $80 \%$ & $53.33 \%$ & $60 \%$ & $60 \%$ \\
\hline $\boldsymbol{E S} \mathbf{P}<\mathbf{0 . 0 0 0 1}$ & $26.66 \%$ & $53.33 \%$ & $33.33 \%$ & $40 \%$ & $40 \%$ \\
\hline
\end{tabular}

Tables 1 and 2. Statistical results of DMC-TP in control cases compared to intra-tumor, peri-tumor and non-tumor regions in case studies, depending on the presence of $H$. pylori

Legend: $C=$ control (without gastric malignancy); $R M=$ resection margin most distant from tumor; $I T=$ intra-tumor area; $L T I F=$ lateral tumor invasion front; $D T I F=$ deep tumor invasion front (in the in-depth of gastric wall (> pT3)); NGW= normal gastric wall. $H P=$ Helicobacter pylori. $N S=$ not statistically significant; $S S=$ statistically significant $(P<0.05) ; E S=$ extremely statistically significant. $P=$ value for statistical significance.

b1. The results in Tables 1 and 2 allow a series of specific conclusions about the role of mast cells; thus we provide clues concerning the changes brought by gastric malignancy by characterization of some aspects of tumor microenvironment through the presence/distribution of mast cells; we performed comparisons both within each category $(\mathrm{HP}-/ \mathrm{HP}+)$ and between categories (HP- vs. $\mathrm{HP}+$ ), the latter being able to provide insets about the influence of presence of infection on DMC-TP in tumor cases. 
When comparing cases with each matched controls at the level of resection margin distant from tumor (RM vs. C), we noticed that HP presence associates an increased DMC-TP in controls.

On the other hand, since $2 / 3$ of HP- cases showed statistical significance differences in DMC$\mathrm{TP}$ values between controls and RM in tumor cases (internal control of tumor cases) that allow interpretation either as a reduced inflammatory reaction in controls or as a possible influence of tumor environment able to generate increased mobilization of mast cells in the gastric wall most distant from the tumor [22-24]. Either way, this would support the idea of an immune response from the host, mobilized by / in the presence of the tumor. The last comment is also supported by the highly statistically significant results of the comparison C/IT in HP- cases as well as the results of the $\mathrm{C} / \mathrm{NGW}$ comparison, both showing more numerous mast cells in the tumor (IT) and in the gastric wall distant from tumor (NGW), compared with gastric wall of control cases (C).

b2. We statistically compared data from different areas of the same case of the study group (Tables 3 and 4), measuring DMC-TP in frank tumor areas and comparing the results with data from other regions of the mucosa / gastric wall of the same case, S HP- and S HP +; thus we observed the peculiar host's way of response consisting in mobilization of the mast cells to the gastric wall affected by a neoplastic process; we note particularities in the presence of mast cells in the tumor (IT) compared to those in the invasion front, nontumor gastric wall at distance from tumor and resection margin. Again, comparing cases with and without HP infection, we obtain some insights about the possible influence of this bacterium on the presence of mast cells in gastric tumor lesions.

A first analysis of the results in Tables 3 and 4 allowed the conclusion of a highly significant mobilization of mast cells in tumor invasion fronts (present in $66.66 \%$ of cases in LTIF area and $73.33 \%$ of cases in DTIF area); these findings might imply that the presence of mast cells is the host's response to tumorigenesis-induced changes in order to limit their extension $[25,26]$; this idea (protective role of mast cells against tumor-induced alterations) is also supported by the increased number of mast cells in the gastric wall distantly located from tumor (NGW).

In $80 \%$ of cases of infection with Helicobacter pylori DMC-TP was significantly lower at IT level in LTIF and DTIF compared to the internal control area $(\mathrm{RM})$ and much smaller $(1 / 2 \div 1 / 4)$ than the average value obtained for them (see Table 5).

Table 3

\begin{tabular}{|l|c|c|c|c|}
\hline \multicolumn{1}{|c|}{ HP- } & IT-RM & IT-LTIF & IT-DTIF & IR-NGW \\
\hline $\begin{array}{l}\mathbf{N S} \\
(\mathbf{P}>\mathbf{0 . 0 5})\end{array}$ & $46.66 \%$ & $13.33 \%$ & $33.33 \%$ & $26.66 \%$ \\
\hline $\begin{array}{l}\mathbf{S S} \\
(\mathbf{P}<\mathbf{0 . 0 5})\end{array}$ & $53.33 \%$ & $86.66 \%$ & $66.66 \%$ & $73.33 \%$ \\
\hline $\boldsymbol{E S}$ & $33.33 \%$ & $40 \%$ & $20 \%$ & $26.66 \%$ \\
$\mathbf{P}<\mathbf{0 . 0 0 0 1}$ & $33.33 \%$ & $33.33 \%$ & $20 \%$ & $13.33 \%$ \\
\hline
\end{tabular}

Table 4

\begin{tabular}{|l|c|c|c|c|}
\hline \multicolumn{1}{|c|}{ HP+ } & IT-RM & IT-LTIF & IT-DTIF & IT-NGW \\
\hline $\begin{array}{l}\mathbf{N S} \\
\mathbf{( P > 0 . 0 5})\end{array}$ & $6.66 \%$ & $33.33 \%$ & $26.66 \%$ & $40 \%$ \\
\hline $\begin{array}{l}\mathbf{S S} \\
(\mathbf{P}<\mathbf{0 . 0 5})\end{array}$ & $93.33 \%$ & $66.66 \%$ & $73.33 \%$ & $60 \%$ \\
\hline $\mathbf{E S}$ & $60.00 \%$ & $26.66 \%$ & $33.33 \%$ & $40 \%$ \\
$\mathbf{P}<\mathbf{0 . 0 0 0 1}$ & $53 \%$ & $13.33 \%$ & $26.66 \%$ & $33.33 \%$ \\
\hline
\end{tabular}

Tables 3 and 4. Statistical results of intra-tumor DMC-TP in comparative case studies of non-tumor and peri-tumor regions depending on the presence of $H$. pylori

Legend: $C=$ control (without gastric malignancy); $R M=$ resection margin most distant from tumor; $I T=$ intra-tumor area; LTIF = lateral tumor invasion front; DTIF $=$ deep tumor invasion front $>$ pT3)); $N G W=$ normal gastric wall. $H P=$ Helicobacter pylori. $N S=$ not statistically significant; $S S=$ statistically significant $(P<0.05) ; E S=$ extremely statistically significant. $P=$ value for statistical significance. 
Table 5

Average values of DMC-TP in control case and in intra-, peri- and non-tumor areas

\begin{tabular}{|l|c|c|c|c|c|c|}
\hline \multicolumn{1}{|c|}{ *H.pylori } & M & RM & IT & FL & FP & NGW \\
\hline \multirow{2}{*}{ Hp present } & 11.46 & 16.73 & 7.33 & 8.2 & 7.33 & 9.53 \\
& $(+9.54 /-7.46)$ & $(+13.27 /-24)$ & $(+21.67 /-5.33)$ & $(+11.80 /-6.2)$ & $(+11.80 /-6.2)$ & $(+7.67 /-4.33)$ \\
\hline \multirow{2}{*}{ Hp absent } & 17.9 & 18 & 15.86 & 17.46 & 18.33 & 14.5 \\
& $(+33.1 /-13.9)$ & $(+24 /-12)$ & $(+23.14 /-2.86)$ & $(+19.54 /-1.46)$ & $(+39.67 /-4.33)$ & $(+43.5 /-10.5)$ \\
\hline
\end{tabular}

Legend: $C=$ control (without gastric malignancy); $R M=$ resection margin most distant from tumor; $I T=$ intra-tumor area; LTIF = lateral tumor invasion front; DTIF = deep tumor invasion front (> pT3); NGW = normal gastric wall.

Studies performed on tumor invasion front in the colon have recorded an increase in the number of mast cells at this level [24]; in our HP- cases with gastric tumor, mean values of DMC-TP at the level of tumor invasion front (LTIF and DTIF) were higher or at least closer to those obtained at RM level. The unexpected contrast to significantly higher values of DMC-TP in non-tumor gastric wall (RM) could be attributed to the action of HP on mucous membrane untransformed by the tumor, the presence of the bacterium causing an accumulation of mast cells at this level [28]. The tumor, in turn, in advanced stages of evolution, does not seem to be regarded by the body host as a foreign presence. However, significantly lower values of DMC-TP at this level, compared with those of the NGW and RM, show the tumor effect on the surrounding tissue, causing an attenuated immunomodulation response [2, 9, 28]. Statistically significant results are mentioned: comparative expression between the distal limit of tumor resection (RM) as control case and tumor (IT) $\mathrm{P}_{\mathrm{RM}-/ \mathrm{TT}-}=0.5794$, lateral tumor invasion front (LTIF) $\mathrm{P}_{\text {RM-LTIF- }}=0.9194$ and deep tumor invasion front (DTIF) $\mathrm{P}_{\mathrm{RM}-/ \mathrm{DTIF}}=0.8105$, respectively gastric wall at $10-15 \mathrm{~cm}$ tumor distance $(\mathrm{NGW}) \mathrm{P}_{\mathrm{RM}-\mathrm{NGW}}=$ 0.5191 .

c. Comparative results of average density values of tryptase-positive mast cells at intratumor (IT), peri-tumor (LTIF and DTIF) level and distant from tumor (NGW) depending on "internal control" (RM) - in lots without or with HP infection

c1. Lot of cases with non-tumor gastric pathology (C HP-) and tumor (S HP-) without infection with HP (BMT I-XV)

Considering DMC-TP values within cases without HP infection, comparisons between different regions, respectively non-tumor (NGW and RM), peri-tumor (LTIF, DTIF) and intra-tumor (IT) failed to offer statistically significant; similar studies in $\mathrm{HP}+$ cases unveiled significant differences in DMC-TP values. c2. Lot of cases with non-tumor gastric pathology $(\mathrm{C} H \mathrm{H}+)$ and tumor $(\mathrm{S} H \mathrm{HP}+$ ) with Helicobacter pylori infection $(X V I-X X X)$

Comparative expression of density of tryptase-positive mast cells between the distal limit of tumor resection (RM) as control case and tumor (IT) was highly statistically significant $\left(\mathrm{P}_{\mathrm{RM}+/ I \mathrm{~T}^{+}}=\right.$ $0.0005)$, as well as comparison with lateral tumor invasion front (LTIF): $\mathrm{P}_{\mathrm{RM}+/ \mathrm{LTIF}+}=0.0034$, deep tumor invasion front: $\mathrm{P}_{\mathrm{RM}+/ \mathrm{DTIF}+}<0.000$ and normal gastric wall (NGW): $\mathrm{P}_{\mathrm{RM}+/ \mathrm{NGW}+}=0.0016 \mathrm{DMC}-\mathrm{TP}$ values.

In all $\mathrm{HP}+$ cases, without exception, DMC$\mathrm{TP}$ values were significantly higher or, in a few cases, at most equal to the distal margin of resection of the tumor (non-tumor wall RM) compared to peri-tumor areas (LTIF, DTIF) and tumor (IT).

\section{d. Statistical comparisons between DMC-TP values depending on the presence/absence of H. pylori}

In case studies with and without Helicobacter pylori DMC-TP showed statistically significant results at the frontline of tumor invasion (lateral and deep): $\quad \mathrm{P}_{\text {LTIF-/LTIF+ }}=0.0160$, respectively $\mathrm{P}_{\text {DTIF-DTIF }}=0.0202$, but also statistically insignificant results, at the level of resection most distant from tumor: $\mathrm{P}_{\mathrm{RM}-\mathrm{RM}+}=0.9203$ ) or even not statistically significant, in tumor: $\mathrm{P}_{\mathrm{IT}-/ \mathrm{IT}+}=0.1025$.

The presence of significantly more mast cells in lateral tumor invasion front LTIF compared with gastric wall most distant from tumor (RM) in HPcases support the theory of the promoter role for tumorigenesis of mast cells [29]. Also we found that the mean value of DMC-TP is more than double in DTIF area in HP- cases compared with those with documented bacterium infection. This difference could be explained by the fact that chronic infection with HP partially depletes the host's local immune mechanisms, so the defense response to neoplasia, although present, is more attenuated than in the case of a tumor on a noncolonized mucosa. On the other hand, the magnitude of the immune-limitation response of the host to the tumor growth could be interpreted as signifi- 
cantly higher in the case of neoplastic stimuli, rather than infectious ones [2,30]. Although DMCTP values were found significantly increased in the most distal tumor wall included in the surgical resection part (result recorded at the end of paragraph c.), comparative statistical evaluation of DMC-TP in normal gastric wall (NGW) in HP- vs. $\mathrm{HP}+$ cases failed to offer statistically significant results $(P=0.2219)$. Therefore, in HP + cases the presence of the bacterium does not cause further mobilization of mast cells at a distance of $10-15 \mathrm{~cm}$ from the tumor, DMC-TP values being similar at this level whether or not the patient presents a superimposed infection: mobilized mast cells are "captured" by the immune response to the tumor's presence, without significantly interfering with the host's immune response to the presence of the bacterium, and also without "emphasizing" mast cells mobilization [29, 31].

\section{CONCLUSIONS}

The results obtained in our study are similar with several other works published in medical literature. Thus, some of them support the protective role of mast cells, part of the host's immune response to limit tumor growth; in these cases, the presence of mast cells can be interpreted as the host's response to changes induced by tumor in the sense of limiting it, an idea supported by the increased number of mast cells in gastric wall located distant from tumor; the magnitude of the host's immune response to limit tumor growth was significantly higher to neoplastic stimuli rather than infectious ones. Other results support the hypothesis of a tumorigenic role for mast cells. Part of our results showed the capacity of tumor environment in generating increased mobilization of mast cells in a gastric wall affected by a neoplastic process, this process occurring also at distance from tumor. These findings support the idea of an immune response from the host, mobilized by/in the presence of the tumor.

In S HP + cases the presence of the bacterium does not seem to cause a further mobilization of mast cells at a distance of $10-15 \mathrm{~cm}$ from the tumor; the values obtained in our study were similar to those obtained in the absence of HP; mobilized mast cells appear to be "captured" by the host's immune response in the presence of a tumor with long evolution without interfering significantly with the immune response in the presence of bacterium and without "emphasizing" mast cells mobilization. On the other hand, we have talked about a true "marker" that the tumor imprints in advanced stages (over pT3) on surrounding tissue, as an attenuated immunomodulatory response, so that apparently overlapping HP presence does not cause global mobilization of mast cells determining final values close to those obtained in S HP- cases.

Another conclusion refers to gastric epithelial tumors $v s$. non-epithelial tumors. In these cases, stromal component of epithelial tumors proved an increased tropism for inflammatory elements compared with non-epithelial tumors; no major differences in mobilizing mast cells were associated with the presence of HP (or the lack of it) in any of the two tumor categories. Also, inflammatory lesions accompanied by preneoplastic changes as well as non-tumor gastric lesions in patients with neoplasia other than gastric, have removed bacterial etiology from the forefront of mobilizing causes of MC.

Therefore, as it resulted from our study, we can claim the involvement of mast cells in the creation of the tumor microenvironment, supporting and/or inhibiting tumor growth; intra- and peritumor decrease and their mobilization at distance would focus mainly on the protective role of MC. As already mentioned, the presence of HP infection was not found to cause significant changes in terms of mobilizing mast cells in the gastric wall with advanced tumors, with minimum stage III TNM.

\section{Abbreviation list}

Control - C

Deep tumor invasion front - DTIF

Extremely statistically significant - ES

Helicobacter pylori - HP

Intra-tumor area - IT

Lateral tumor invasion front - LTIF

Normal gastric wall sampled $5 \mathrm{~cm}$ or more distant from the tumor-NGW

Not statistically significant - NS

Resection margin most distant from tumor - RM

Study - S

Statistically significant $(\mathrm{P}<0.05)-\mathrm{SS}$

Acknowledgement. This paper is supported by the Sectorial Operational Programme Human Resources Development (SOP HRD), financed from the European Social Fund and by the Romanian Government under the contract number POSDRU/ $159 / 1.5 / \mathrm{S} / 137390$.

Context. Cancerul gastric continuă să fie în plutonul fruntaş al cauzelor de mortalitate. Semnificativ de multe dintre studiile recente dovedesc implicarea 
directă sau indirectă a mastocitului, cu un rol complex atât pro- cât şi anticreştere tumorală.

Obiective. A obiectiva corelațiile existente între expresia mastocitelor şi prezența infecției cu H. pylori, în funcție de natura neoplazică a afectării gastrice.

Materiale şi metode. Studiul a fost efectuat pe mostre din peretele gastric obținute de la 30 de pacienți cu cancer gastric versus 30 subiecți asemănători ca vârstă şi sex care au suferit intervenții chirurgicale gastrice pentru alte boli nonneoplazice. Criteriile de includere pentru studiu au fost etapele maligne T3 / T4 cu metastaze ganglionare regionale. Pentru fiecare caz din grupul de studiu, au fost analizate DMC-TP în cinci arii diferite ale aceluiaşi specimen din gastrectomie: zona intratumorală, frontul de invazie în profunzime şi lateral, mostra de țesut gastric normal la $5-10 \mathrm{~cm}$ sau mai îndepărtat de tumoră şi cea mai indepărtată margine de rezecție.

Rezultate. Dintre rezultatele obținute, menționăm faptul că, independent de prezența sau nu a bacteriei, studiul a înregistrat o valoare a DMC-TP semnificativ mai redusă la pacienții bărbați. În regiunile cu leziuni inflamatorii însoțite de modificări preneoplazice şi în cazurile martor provenite de la pacienți cu altă neoplazie decât gastrică, nivelul DMC-TP a fost peste media cazurilor cu patologie inflamatorie corelată cu prezența H. pylori, scoțând etiologia bacteriană din primplanul cauzelor de mobilizare a MC.

Concluzie. Prezența infecției cu H. pylori nu s-a dovedit a determina modificări semnificative în privința mobilizării mastocitelor în peretele gastric cu tumori avansate, cu stadiul TNM minim III.

Corresponding author: Gianina Micu, "Colentina” Clinical Hospital, Department of Pathology, Bucharest, Romania, 19-21 Sos. Ştefan cel Mare, Bucharest E-mail: dr_geanina@yahoo.com

\section{REFERENCES}

1. FOX JG, WANG TC. Inflammation, atrophy and gastric cancer. J Clin Invest 2007, 117: 60-9.

2. HOUGHTON J, WANG T. Helicobacter pylori and gastric cancer: a new paradigm for inflammation-associated epithelial cancers. Gastroenterology 2005, 128: 1567-78.

3. NAKAJIMA S, BAMBA N, HATTORI T. Histological aspects and role of mast cells in Helicobacter pylori-infected gastritis. Alimentary Pharmacology and Therapeutics, Supplement. 2004; 20(1): 165-70.

4. MUKHERJEE S, BANDYOPADHYAY G, DUTTA C, BHATTACHARYA A, KARMAKAR R, BARUI G. Evaluation of endoscopic biopsy in gastric lesions with a special reference to the significance of mast cell density. Indian Journal of Pathology and Microbiology. 2009; 52(1): 20-4.

5. DALTON DK, RANDOLPH JN. The roles of mast cells in anticancer immunity. Cancer Immunology, Immunotherapy 2012 ; 61(9): 1511-20.

6. MA Y, HWANG RF, LOGSDON CD, ULLRICH SE. Dynamic Mast Cell-Stromal Cell Interactions Promote Growth of Pancreatic Cancer. Cancer Research, 2013, 73: 3927.

7. WHITESIDE TL. The tumor microenvironment and its role in promoting tumor growth. Oncogene 2008, 27: 5904-12.

8. SAUTÈS-FRIDMAN C, CHERFILS-VICINI J, DAMOTTE D, FISSON S, FRIDMAN WH, HERVÉ W, CREMER I, DIEUNOSJEAN MC. Tumor microenvironment is multifaceted. Cancer and Metastasis Reviews, 2011, 30(1):13-25.

9. RIBATTI, D, VACCA, A, NICO, B, CRIVELLATO, E, RONCALI, L, DAMMACCO, F. The role of mast cells in tumour angiogenesis. British Journal of Haematology, 2001, 115: 514-521.

10. MANGIA, A, MALFETTONE, A, ROSSI, R, PARADISO, A, RANIERI, G, SIMONE, G, RESTA, L. Tissue remodelling in breast cancer: human mast cell tryptase as an initiator of myofibroblast differentiation. Histopathology, 2011, 58:1096-1106.

11. THEOHARIDES TC, ALYSANDRATOS K, ANGELIDOU A, DELIVANIS D, SISMANOPOULOS N, ZHANG B, et al. Mast cells and inflammation. Biochimica et Biophysica Acta - Molecular Basis of Disease. 2012; 1822(1):21-33.

12. SIEMANN, DW. Tumor Microenvironment. Publisher John Wiley \& Sons, 2010, pp.8-10.

13. NORRBY, K. Mast cells and angiogenesis. APMIS, 2002, 110:355-371.

14. WAN WH, FORTUNA MB, FURMANSKI P. A rapid and efficient method for testing immunohistochemical reactivity of monoclonal antibodies against multiple tissue samples simultaneously. J. Immunol Methods. 1987, 103(1):121-9.

15. TAWEEVISIT M, KLAIKAEW N. Correlation between mast cell density and histological parameters in Helicobacter pyloriassociated gastritis. Asian Biomedicine. 2011; 5(1):163-7. 
16. YOSHII M, JIKUHARA A, MORI S, IWAGAKI H, TAKAHASHI HK, NISHIBORI M, et al. Mast cell tryptase stimulates DLD-1 carcinoma through prostaglandin-and MAP kinase-dependent manners. Journal of Pharmacological Sciences. 2005; 98(4):450-8.

17. HODGES K, KENNEDY L, MENG F, ALPINI G, FRANCIS H. Mast cells, disease and gastrointestinal cancer: A comprehensive review of recent findings. Transl. Gastrointest. Cancer. 2012, 1(2): 138-150.

18. KHAZAIE K, BLATNER S, KHAN MW, GOUNARI F, GOUNARIS E, DENNIS K, et al. The significant role of mast cells in cancer. Cancer Metastasis Rev. 2011, 30(1): 45-60.

19. QUESNEL B. Tumor dormancy and immunoescape. APMIS 2008, 116(7-8): 685-694.

20. NECHUSHTAN H. The complexity of the complicity of mast cells in cancer. Int J Biochem Cell Biol. 2010, 42(5): 551-4.

21. MARICHAL T, TSAI M, GALLI SJ. Mast cells: potential positive and negative roles in tumor biology. Cancer Immunol Res. 2013, 1(5): 269-79.

22. REBBER LL, MARICHAL T, GALLI SJ. New models for analyzing mast cell functions in vivo. Trends Immunol. 2012, 33(12): 613-625.

23. HÜTTER G, GANEPOLAS S, THIEL E, HOFMANN WK. Inhibition of mast cell tryptase activity. A new therapeutic target against malignancy induced angiogenesis. Bioscience Hypotheses, 2008, 4(1): 213-217.

24. KHATAMI M. Unresolved inflammation: 'immune tsunami' or erosion of integrity in immune-privileged and immuneresponsive tissues and acute and chronic inflammatory diseases or cancer. Expert Opin Biol Ther. 2011, 11(11): 1419-32.

25. KHATAMI M. Chronic Inflammation: Synergistic Interactions of Recruiting Macrophages (TAMs) and Eosinophils (Eos) with Host Mast Cells (MCs) and Tumorigenesis in CALTS. M-CSF, Suitable Biomarker for Cancer Diagnosis! Cancers (Basel), 2014, 6(1): 297-322.

26. WALKER ME, HATFIELD JK, BROWN MA. New insights into the role of mast cells in autoimmunity: evidence for a common mechanism of action? Biochim Biophys Acta. 2012, 1822(1): 57-65.

27. LIU J, ZHANG Y, ZHAO J, YANG Z, LI D, KATIRAI F, et al. Mast cell: insight into remodeling a tumor microenvironment. Cancer Metastasis Rev. 2011, 30(2): 177-84.

28. DA SILVA E, JAMUR M, OLIVER C. Mast Cell Function: A New Vision of an Old Cell. J Histochem Cytochem. 2014, 62(10): 698-738.

29. GALINSKY DS, NECHUSHTAN H. Mast cells and cancer--no longer just basic science. Crit Rev Oncol Hematol. 2008, 68(2): 115-30.

30. AMMENDOLA M, SACCO R, DONATO G, ZUCCALA V, RUSSO E, LUPOSELLA M, et al. Mast cell positivity to tryptase correlates with metastatic lymph nodes in gastrointestinal cancer patients treated surgically. Oncology, 2013, 85(2): 111-6.

31. PAYNE V, KAM PC. Mast cell tryptase: a review of its physiology and clinical significance. Anaesthesia, 2004, 59(7): 695-703.

Received April 29, 2015 